\title{
Influence of the length and location of implants on distal extension removable partial dentures: finite element analysis
}

\author{
Jin-Hee Kim, Jin-Hyun Cho, Cheong-Hee Lee* \\ Department of Prosthodontics, School of Dentistry, Kyungpook National University, Daegu, Republic of Korea
}

Purpose: To evaluate the effects of implant location and length on stress distribution and displacement in osseointegrated-implants that were associated with mandibular distal extension removable partial dentures (DERPD). Materials and Methods: A sagittally cut model with the \#33, \#34 teeth and a removable partial denture of the left mandible was used. Seven models were designed with NX 9.0. Models A, B, C had implants with lengths of $11,6,4 \mathrm{~mm}$, respectively, under the denture base of the \#37 artificial tooth. Models D, E, F had implants with lengths of 11, 6, $4 \mathrm{~mm}$, respectively, under the denture base of the \#36 artificial tooth. Model $\mathrm{G}$ did not have any implants. Axial force $(250 \mathrm{~N})$ was loaded on \#36 central fossa. The finite element analysis was performed with MSC Nastran. Von Mises stress maps were plotted to visualize the results. Results: The models of \#37 implant placement showed much lower stress concentration on the surrounding bone of the implant compared with \#36. The \#36 implant position tended to reduce displacement more than \#37. Conclusion: When an IARPD is designed, the distal positioning of implant placement has more advantages in the edentulous bone of DERPD on the prognosis of short implants and the stress distribution of edentulous alveolar bone. Using implants with longer lengths are important for stress distribution. However, Additional studies are necessary of the effects of length on implant survival. (J Dent Rehabil Appl Sci 2015;31(3):186-94)

Key words: implant-associated removable partial denture; distal extension removable partial denture; implant length; stress distribution

\section{서론}

오늘날 임플란트의 대중화로 부분 또는 완전 무치악 부위의 치료방법이 고정성 보철물이나 가철성 국소의치 또는 총의치 등의 전통적인 치료방법에서 임플란트 식립 후 그 상부에 보철하는 방법으로 상당수 대체되었다. 그 러나 임플란트 보철물이 가지는 여러가지 장점에도 불구 하고, 해부학적 또는 경제적 이유 등으로 여전히 기존 치 료방법 또한 병행되고 있다. 그리고 임플란트와 기존 치 료의 복합적 방식도 제안되어 왔는데, 이러한 방법은 수 술과 연관된 관혈적 위험은 줄이면서 기능적 효율성은

*Correspondence to: Cheong-Hee Lee

Professor, Department of Prosthodontics, Kyungpook National University Dental Hospital, 2175, Dalgubeoldae-ro, Jung-gu, Daegu, 41904, Republic of Korea

Tel: +82-53-600-7673, Fax: +82-53-427-0778, E-mail: chlee@knu.ac.kr

Received: June 22, 2015/Last Revision: July 29, 2015/Accepted: July 30, 2015
높이고, 기존 치료방식의 문제점을 줄여, 환자의 편안함 을 증가시키는 장점이 있다. ${ }^{1-5}$

하악 부분 무치악 증례 중, 치아지지형 국소의치로 회 복하는 Kennedy class III와는 다르게 Kennedy class I이 나 class II 증례는 가철성 국소의치로 회복 후 후방연장 무치악부의 지속적인 골흡수와 의치상의 동요, 의치상 하부 연조직 자극, 저작기능의 불완전 회복 ${ }^{6-8}$ 등이 문제 가 되고 있다. 이는 치아와 점막의 서로 다른 물리적 특 성에 기인하는 것으로, ${ }^{8,9}$ 치아와 잔존치조골 상방 점막으 로의 균형있는 하중분산을 위해 여러가지 술식을 적용하 고 있으나, ${ }^{5,10,11}$ 위와 같은 문제를 피할 수 없는 경우도 많 
다. ${ }^{10,11}$ 이에 후방 무치악부에 임플란트를 식립하여 문제 점을 경감하려는 시도와 연구가 여러 문헌에서 보고되 고 있다. ${ }^{3,4,12,13}$

기존방식의 후방연장 국소의치에서는 최후방 지대치 를 지점으로 하는 지렛대의 power arm이 형성되어 저작 시 회전력이 발생한다. ${ }^{13,14}$ 그러나, 후방 무치악부에 임 플란트를 식립하면 국소의치의 지렛대 작용을 제한할 수 있다..$^{3-5}$ 즉, Kennedy class I의 치아-점막 지지구조에 서 Kennedy class III 형태의 치아-임플란트 지지구조로 변화하게 되는 것이다. ${ }^{3,15}$ 더 나아가, 후방 구치부에 식 립된 임플란트 상부에 보철물을 제작하여 국소의치를 유지하기 위한 지대치로 사용하지 않고, 의치상 하방에 위치시켜 지지형식으로 사용하는 것은 임플란트에 작용 하는 측방력을 줄여주어 임플란트에 유리한 설계로 생 각된다. ${ }^{1,16}$ 또한, 이와 관련된 성공적인 사례가 보고되고 있어, 구치부에 임플란트를 식립하여, 지지를 얻는 방법 은 치료의 선택 범위를 넓히는 하나의 방법으로 정립될 수 있다. ${ }^{3,4,15,17-19}$

그러나, 이러한 사례들은 대부분 임플란트 식립 부위 의 골양(bone volume)이 충분하여, 길이가 긴 임플란트 를 사용할 수 있었다. ${ }^{20}$ 즉, 골양이 부족한 환자에게 술식 을 적용한 경우가 거의 보고되지 않아, 임상에 적용하기 위한 가이드라인이 부족한 실정이다. 물론, 충분한 골양 을 얻기 위한 수직적 치조골 증대술이 있을 수 있으나 이는 경제적 부담, 시술의 어려움이나 후유증이 크고 환 자의 심리적 거부감이 심하여 현실적으로 실행하기 어 려운 부분이 많다. ${ }^{5}$ 따라서, 가용 치조골의 양이 충분하 지 않은 후방연장 국소의치 증례에서도 짧은 임플란트 가 의치 지지와 무치악부의 치조골을 보존하는 기능을 수행할 수 있는지, 충분히 연구해볼 만한 가치가 있다.

Cunha 등 ${ }^{21}$ 과 Verri 등 ${ }^{5}$ 은 하악 후방연장 국소의치에 서 임플란트의 위치와 길이 그리고 직경이 어떠한 영향 을 미치는지 알아보는 유한요소 분석 실험에서, 임플란 트를 지대치에 근접시켜야 지대치의 응력분산이 유리 하다고 언급하며, 길이가 길고 굵은 임플란트 식립을 추 천하였다. 그러나, 임상에서 충분히 긴 임플란트가 이미 성공적으로 사용되고 있고 짧은 임플란트의 식립을 기 대하고 있는 상황에서, 짧은 임플란트가 응력분포에 미 치는 영향에 대한 비교 분석은 이루어지지 않았다.

그러므로, 이번 연구에서는 하악 후방연장 부분 무치 악 증례에서 임상적으로 성공하고 있는 충분한 길이의 임플란트와 다양한 짧은 임플란트가 서로 다른 위치에
있을 때, 하중 하에서 임플란트와 지대치, 그리고 무치 악부에 나타나는 응력분포와 변위를 유한요소 분석을 통해 알아보고자 한다.

\section{연구 재료 및 방법}

\section{1. 연구 대상}

하악 좌측 제 2 소구치, 제 1 대구치 및 제 2 대구치가 소 실된 sagittal cut의 후방연장 치형모형을 이용하여, 하 악 좌측 견치와 제 1 소구치의 치관과 치근을 Wheeler ${ }^{22}$ 가 기술한 평균 치아의 형태로 설계하였다. 여기에 제 1 소구치를 지대치로 원심에 레스트 시트를 형성하고 레스트를 안착한 하악 편측 후방연장 국소의치를 기 본모형으로 하였다. NX 9.0프로그램(Siemens, Berlin, Germany)을 사용해 2차원 유한요소 모형으로 설계하 였으며, bottom line을 고정하고, $\mathrm{X}$ (수평)와 $\mathrm{Y}$ (수직) 축 의 자유도를 허용하였다. 이때 무치악 부위점막의 두께 는 $2 \mathrm{~mm}$, 치밀골의 두께는 $2 \mathrm{~mm}$, 치근 주위 치조백선 의 두께는 $0.25 \mathrm{~mm}$, 그리고 치주인대는 $0.25 \mathrm{~mm}$ 로 설 정하고, 치조골은 백아법랑경계에 $3 \mathrm{~mm}$ 낮게 형성하 였다. 이를 바탕으로 Healing abutment (height $2 \mathrm{~mm}$, Megagen)와 위치와 길이를 달리하는 임플란트(3.75 $\mathrm{mm}$, External hex type)를 포함한 실험모델을 설계하 였다(Table 1). 이때 적용된 요소형태(element type)는 CPLST S6 (2D plane stress triangular parabolic element including contact)이며 크기는 평균 $0.2 \mathrm{~mm}$ 로 하였으나 주요 관찰부위인 무치악부 치밀골, 지대치와 치조백선, 임플란트 주위의 골조직 등은 좀 더 치밀하게 구성하여 요소의 수가 약 62,000 이상이었다. 그리고 각 구성 성분 의 물성치는 선학들의 연구를 참조하였다(Table 2).

\section{2. 연구 방법}

하악 좌측 제 1 대구치의 중심와에 $250 \mathrm{~N}$ 의 힘을 단일 수직부하 적용하였으며, 응력분석은 유한요소 분석프로 그램인 MSC Nastran (NASA, Washington D.C., USA) 을 이용하여 von-Mises stress와 변위를 관찰하였다. 그 리고 정량적 비교를 하기 위하여 응력의 집중이 되거나 중요한 부위를 중심으로 임플란트 주위에 1 - 6번을, 자 연치 주위에 7 - 10번을, 그리고 무치악부에는 11 - 13번 의 참고점을 설정하였다. 모델 $\mathrm{D}, \mathrm{E}, \mathrm{F}$ 에서는 임플란트 
Table 1. Control and experimental models

\begin{tabular}{ccc}
\hline Model & Implant Length $(\mathrm{mm})$ & Implant Position \\
\hline A & 11 & 2nd molar \\
B & 6 & \\
C & 4 & 1st molar \\
D & 11 & \\
E & 6 & \\
F & 4 & \\
G & control & \\
\hline
\end{tabular}

Table 2. Material properties of components

\begin{tabular}{lcl}
\hline \multicolumn{1}{c}{ Material } & $\begin{array}{c}\text { Young's Modulus } \\
(\mathrm{GPa})\end{array}$ & Poisson's Ratio \\
\hline Titanium & 110 & 0.33 \\
Acrylic resin & 2.2 & 0.4 \\
Cobalt Chromium & 211 & 0.3 \\
Dentin & 18.6 & 0.31 \\
Gingiva & 0.0196 & 0.3 \\
Cortical bone & 13.7 & 0.3 \\
Cancellous bone & 1.37 & 0.3 \\
Periodontal ligament & 0.0689 & 0.45 \\
Stainless steel & 201 & 0.3 \\
\hline
\end{tabular}

후방 제 2 대구치 하방 치밀골에 응력집중이 있어 14 번 참고점을 추가하였으며, 모델 $\mathrm{G}$ 에는 응력집중이 있는 제1과 2대구치 사이 하방 치밀골에 15번 참고점을 추가 하였다(Fig. 1).

\section{결과}

\section{1. 응력 분석}

각 모델의 von-Mises stress의 분포도(Fig. 2)와 참고점 의 응력값(Table 3)을 얻어서 분석하였다. 대조군인 모 델 $\mathrm{G}$ 에서는 응력이 지대치에 상대적으로 집중되고 무 치악부에는 응력이 넓은 면적에 분포하나 상대적으로 집중되지는 않았다.

1) 임플란트 길이에 따른 응력분산 효과
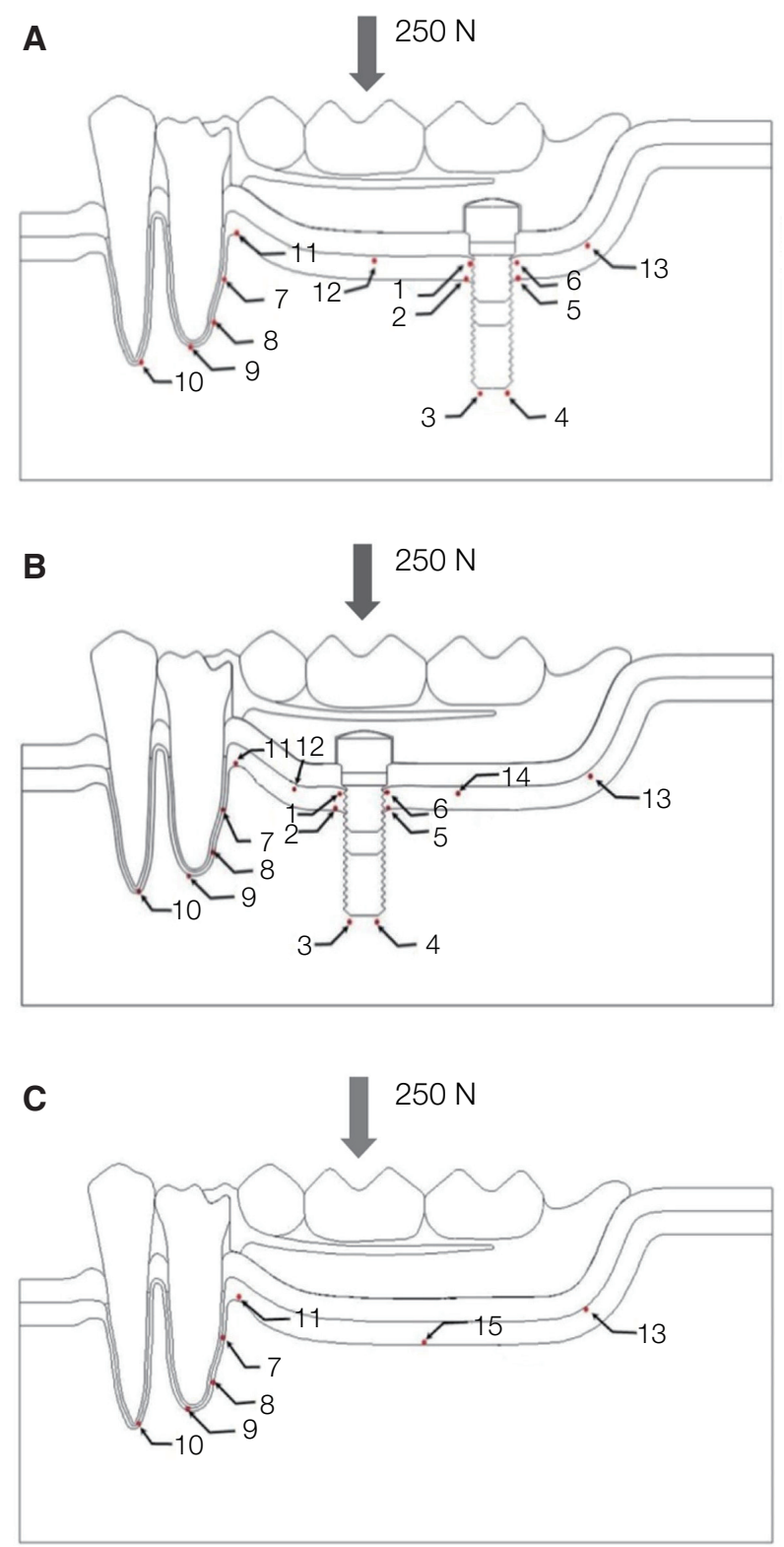

Fig. 1. Reference points for reading the von-Mises stress and the displacement in 2-dimensional drawing for finite element analysis. (A) model A, B, C, (B) model D, E, F, (C) model G.

임플란트 식립위치에 관계없이 임플란트 길이가 짧을 수록 임플란트 주위 치밀골에 응력이 심하게 집중하였 으나, 임플란트 근단부 해면골에 미치는 응력집중은 적 으나마 감소하였으며, 무치악부에 분산되는 응력은 증 
가하였다. 지대치에 미치는 응력에 대하여서는 길이가 큰 영향을 주지는 못하였다.

임플란트 경부 참고점 1 과 6 번을 이용하여 응력의 근 원심 평균을 내어 비교하여 보면, 모델 A, B, C에서는 모 델 $\mathrm{A}$ 에 비하여 모델 $\mathrm{B}$ 는 약 2.3 배, 모델 $\mathrm{C}$ 는 약 3 배의 응 력집중이 임플란트 경부 치밀골에 나타났으며, 모델 $\mathrm{D}$, $\mathrm{E}, \mathrm{F}$ 에서도 모델 $\mathrm{D}$ 에 비하여 모델 $\mathrm{E}$ 는 약 1.6배, 모델 $\mathrm{F}$ 는 약 1.9 배의 응력집중이 나타났다.

A
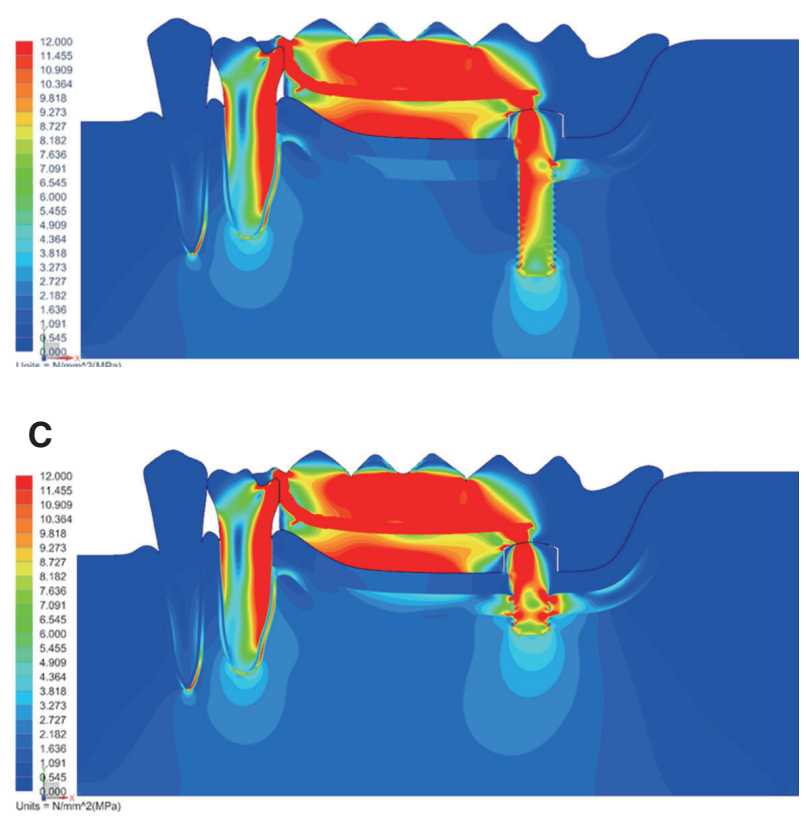

E

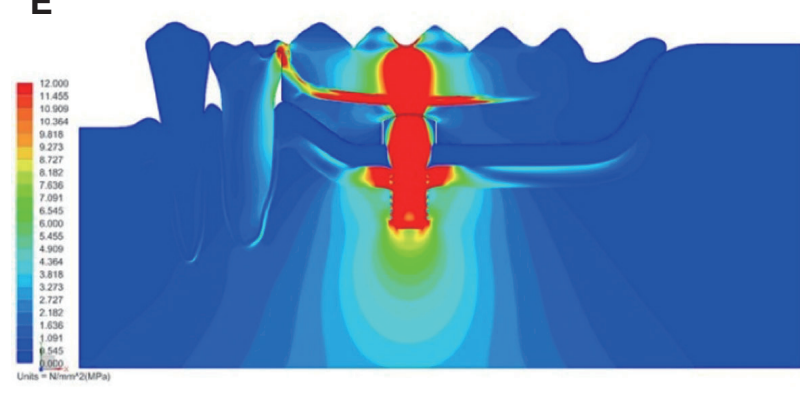

G

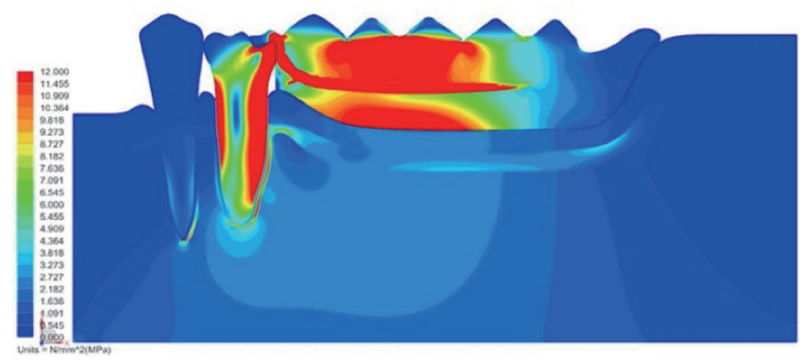

2) 임플란트 위치에 따른 응력분산 효과

무치악부 원심에 임플란트가 식립된 모델 $\mathrm{A}, \mathrm{B}, \mathrm{C}$ 의 경우에는 모델 $\mathrm{D}, \mathrm{E}, \mathrm{F}$ 에 비하여 길이에 상관없이 훨씬 적은 응력집중이 임플란트 주위 골조직에 나타났다. 모 델 $\mathrm{A}, \mathrm{B}, \mathrm{C}$ 의 임플란트 경부 치밀골에서 원심부 응력집 중이 근심보다 높았으며, 참고점 중 1 과 6 번을 비교하면 모델 A에서는 원심인 6 번에서 1 번에 비해 약 10 배의 응 력집중이 관찰되었으나, 모델 $\mathrm{B}, \mathrm{C}$ 에서는 약 1.6배와 1.2 배로 낮아지는 것으로 나타났다. 그러나, 모델 $\mathrm{D}, \mathrm{E}, \mathrm{F}$ 의
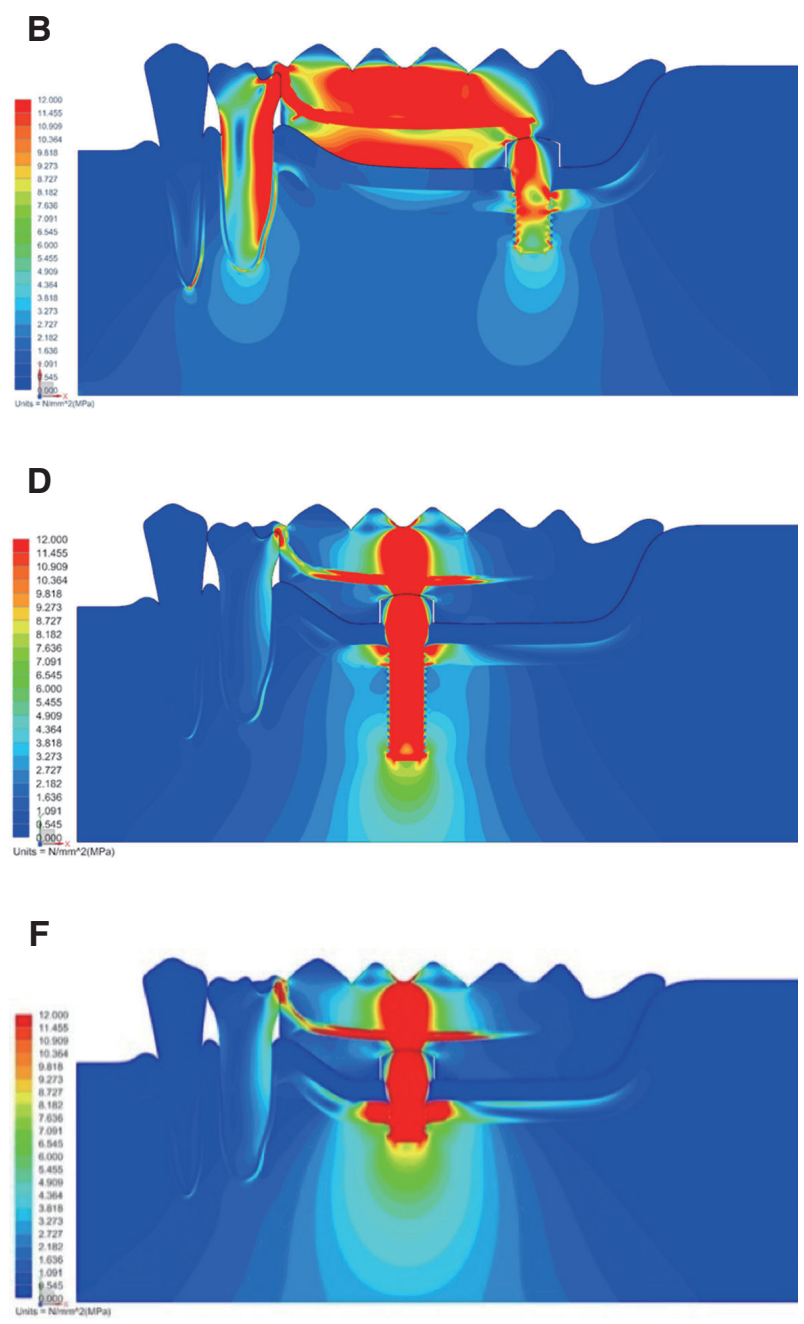

Fig. 2. von-Mises stress distribution of each model. (A) Model A, (B) Model B, (C) Model C, (D) Model D, (E) Model E, (F) Model F, (G) Model G. 
Table 3. von-Mises stress and X \& Y axis displacement of each reference point (RP) in each model (unit; MPa, mm)

\begin{tabular}{|c|c|c|c|c|c|c|c|c|c|c|c|c|c|c|c|c|}
\hline & del & 1 & 2 & 3 & 4 & 5 & 6 & 7 & 8 & 9 & 10 & 11 & 12 & 13 & 14 & 15 \\
\hline \multirow[t]{3}{*}{ A } & stress & 1.01 & 0.634 & 6.3 & 5.69 & 6.25 & 10.28 & 10.4 & 11.49 & 10.15 & 9.91 & 5.06 & 2.4 & 2.22 & & \\
\hline & $\mathrm{X}$ & 0.001 & 0.001 & 0.003 & 0.004 & 0.002 & 0.0009 & -0.001 & -0.005 & -0.007 & -0.007 & -0.001 & 0.0002 & -0.002 & & \\
\hline & $\mathrm{Y}$ & -0.019 & -0.019 & -0.018 & -0.017 & -0.018 & -0.018 & -0.027 & -0.023 & -0.019 & -0.012 & -0.028 & -0.022 & -0.009 & & \\
\hline \multirow[t]{3}{*}{ B } & stress & 9.82 & 6.51 & 5.98 & 5.68 & 11.35 & 15.84 & 10.39 & 11.35 & 9.96 & 9.816 & 5.01 & 3.49 & 3.88 & & \\
\hline & $\mathrm{X}$ & 0.001 & 0.002 & 0.003 & 0.004 & 0.002 & 0.001 & -0.001 & -0.005 & -0.007 & -0.007 & -0.0005 & 0.001 & -0.003 & & \\
\hline & $\mathrm{Y}$ & -0.027 & -0.027 & -0.026 & -0.025 & -0.025 & -0.025 & -0.027 & -0.023 & -0.019 & -0.012 & -0.028 & -0.024 & -0.011 & & \\
\hline \multirow[t]{3}{*}{ C } & stress & 15.77 & 11.5 & 5.72 & 5.19 & 14.92 & 18.77 & 10.4 & 11.32 & 9.92 & 9.79 & 5.06 & 3.99 & 4.54 & & \\
\hline & $\mathrm{X}$ & 0.002 & 0.002 & 0.003 & 0.004 & 0.003 & 0.001 & -0.001 & -0.005 & -0.007 & -0.007 & -0.0003 & 0.001 & -0.003 & & \\
\hline & $\mathrm{Y}$ & -0.031 & -0.03 & -0.03 & -0.028 & -0.028 & -0.028 & -0.027 & -0.023 & -0.019 & -0.012 & -0.028 & -0.024 & -0.011 & & \\
\hline \multirow[t]{3}{*}{ D } & stress & 22.35 & 12.23 & 12.96 & 12.01 & 12.16 & 26.43 & 2.77 & 5.26 & 1.22 & 3.39 & 0.79 & 2.23 & 2.01 & 2.05 & \\
\hline & $\mathrm{X}$ & 0.0002 & -0.0006 & -0.0004 & 0.0006 & 0.0002 & -0.0006 & 0.001 & -0.002 & -0.003 & -0.003 & 0.007 & 0.007 & -0.002 & -0.004 & \\
\hline & Y & -0.036 & -0.036 & -0.034 & -0.034 & -0.036 & -0.036 & -0.012 & -0.01 & -0.007 & -0.003 & -0.014 & -0.02 & -0.004 & -0.017 & \\
\hline \multirow[t]{3}{*}{$\mathrm{E}$} & stress & 35.86 & 23.31 & 12.19 & 12.33 & 23.32 & 41.84 & 2.37 & 5.86 & 0.94 & 4.29 & 1.84 & 4.07 & 2.53 & 4.91 & \\
\hline & $\mathrm{X}$ & 0.0006 & -0.001 & -0.0009 & 0.0005 & 0.0003 & -0.0008 & 0.0005 & -0.004 & -0.005 & -0.040 & 0.01 & 0.01 & -0.002 & -0.005 & \\
\hline & $\mathrm{Y}$ & -0.051 & -0.051 & -0.05 & -0.05 & -0.051 & -0.052 & -0.014 & -0.012 & -0.008 & -0.004 & -0.017 & -0.025 & -0.004 & -0.02 & \\
\hline \multirow[t]{3}{*}{$\mathrm{F}$} & stress & 43.32 & 31.96 & 11.39 & 11.84 & 32.61 & 50.84 & 1.98 & 6.03 & 0.96 & 4.63 & 2.12 & 4.85 & 2.62 & 6.23 & \\
\hline & $\mathrm{X}$ & 0.0007 & -0.001 & -0.001 & 0.0002 & 0.0003 & -0.001 & 0.0002 & -0.005 & -0.005 & -0.004 & -0.011 & 0.01 & -0.002 & -0.005 & \\
\hline & $\mathrm{Y}$ & -0.057 & -0.057 & -0.057 & 0.057 & -0.058 & -0.058 & -0.015 & -0.012 & -0.009 & -0.004 & -0.018 & -0.026 & -0.004 & -0.021 & \\
\hline \multirow[t]{3}{*}{ G } & stress & & & & & & & 11.64 & 12.97 & 11.75 & 15.38 & 9.93 & & 4.01 & & 3.47 \\
\hline & $\mathrm{X}$ & & & & & & & -0.0003 & -0.006 & -0.008 & -0.007 & 0.003 & & 0.0007 & & 0.002 \\
\hline & $\mathrm{Y}$ & & & & & & & -0.028 & -0.023 & -0.019 & -0.011 & -0.03 & & -0.012 & & -0.029 \\
\hline
\end{tabular}

임플란트 경부 치밀골에서 원심부 응력이 근심보다 조 금 높았으나 집중된 응력값에 비하여 그 양이 미미하였 다.

임플란트 경부 참고점 1과 6번을 이용하여 응력의 근 원심 평균을 내어 같은 길이에서 위치에 따른 응력을 비 교하여 보면, 모델 $\mathrm{A}$ 에 비하여 모델 $\mathrm{D}$ 에서 약 4.3배, 모 델 $\mathrm{B}$ 에 비하여 모델 $\mathrm{E}$ 에서 약 3배, 그리고 모델 C에 비 하여 모델 F에서 약 2.7배의 응력집중이 있었다. 모델 D 에서 집중된 응력은 짧은 길이의 모델 $\mathrm{B}, \mathrm{C}$ 보다 높아서 모델 $\mathrm{B}$ 에 비하여 약 1.9배, 그리고 모델 C에 비하여 약 1.4 배의 응력집중이 있었다.

대조군인 모델 $\mathrm{G}$ 에 비하여 지대치에 미치는 응력은 모델 $\mathrm{D}, \mathrm{E}, \mathrm{F}$ 에서 매우 감소한 것을 볼 수 있었으나, 모 델 $\mathrm{A}, \mathrm{B}, \mathrm{C}$ 에는 소량 감소하였다. 후방 무치악부에서는 모델 $\mathrm{A}, \mathrm{B}, \mathrm{C}$ 보다 모델 $\mathrm{D}, \mathrm{E}, \mathrm{F}$ 에서 응력의 집중이 증가 하는 것을 볼 수 있었다.

\section{2. 변위 분석}

전체적 변위를 분석한 결과, 의치의 변위량은 임플란 트를 식립함으로서 다량 감소하며, 특히 위치에 영향을 받아 모델 $\mathrm{D}, \mathrm{E}, \mathrm{F}$ 가 가장 적은 변위량을 보였으나, 임플 란트의 길이에는 큰 영향을 받지 않았다.

참고점에서의 변위를 분석한 결과(Table 3), 모든 모 델에서 $\mathrm{X}$ 축 변위는 $\mathrm{Y}$ 축에 비하여 그 양이 매우 적어 무 시할 수 있을 것으로 사료되며, Y축 변위는 하중이 가해 지면서 모두 하방 변위된 것을 볼 수 있었다. 임플란트 주위 치조골의 하방 변위는 모델 $\mathrm{A}, \mathrm{B}, \mathrm{C}$ 보다 모델 $\mathrm{D}, \mathrm{E}$, $\mathrm{F}$ 에서 더욱 증가하였으며, 임플란트 길이가 짧을수록 더 많은 변위가 일어났다. 또한, 지대치 주위 치조골의 변형은 모델 $\mathrm{D}, \mathrm{E}, \mathrm{F}$ 에서 임플란트가 길수록 적었으나, 모델 $\mathrm{A}, \mathrm{B}, \mathrm{C}$ 에서는 변형량이 거의 차이가 없었다. 무치 악부의 변위는 임플란트의 변위와 의치의 휨에 의해 나 타나는데, 모든 실험모델에서 임플란트와 지대치 중간 
부위의 변위가 더욱 증가하였으며, 임플란트 길이가 짧 을수록 변위량이 증가하였다. 모든 실험모델의 최후방 원심부에는 변위가 적게 나타났으나, 모델 D, E, F에서 는 제 2 대구치 하방 부위도 다량 변위되었다.

\section{총괄 및 고찰}

후방연장 국소의치에 대한 임플란트의 보조적인 사용 은 건전하지 못한 지대치의 보조 혹은 대신에 사용하거 나, ${ }^{19}$ 임플란트 보철물을 지대치로 사용하는 방법 23,24 또 는 무치악부 후방에 임플란트를 식립하여 ${ }^{3,4}$ 후방연장 국소의치의 단점을 보완하는 것이다. 이러한 치료방법 들이 현재 임상에서 성공적으로 이루어지고 있으나 대 부분 충분한 길이의 임플란트가 사용되었다. 이번 연구 에서는 후방연장 국소의치의 무치악부 후방에 임플란트 를 식립하는 경우, 잔존치조골이 적어 짧은 임플란트를 식립하면 응력분산에 어떠한 영향을 주는지 알아보기 위하여 2차원 유한요소법을 사용하여 실험하였다.

국소의치의 무치악부 형태는 다양하다고 할 수 있으 나, 2차원 실험모델에서 레스트의 기능을 형성할 수 있 고 무치악부가 적절하게 형성될 수 있도록 Verri 등 ${ }^{5}$ 의 실험에서와 같이 견치와 제 1 소구치가 있고 후방은 무치 악으로 하는 모형을 설계하였으며 임상에서는 후방연장 증례에서 주로 근심 레스트를 사용하나 이번 실험에서 는 원심 레스트를 형성하였다.

하중을 주는 방법에서, Cunha 등 ${ }^{21}$ 은 의치 교합면 교 두에 균등하게 $10 \mathrm{~N}$ 씩 분산하중을 주어 $50 \mathrm{~N}$ 을 가하기 도 하고, Verri 등 ${ }^{\circ}$ 은 $50 \mathrm{~N}, 100 \mathrm{~N}$, 혹은 $400 \mathrm{~N}$ 의 분산하 중을 주었으나, 본 실험에서는 하악좌측 제 1 대구치의 중심와에 $250 \mathrm{~N}$ 의 힘을 단일 수직부하 적용하였다. 분 산하중보다는 단일 수직하중이 임플란트와 주위 조직에 악영향을 미치는 응력집중이 더욱 많을 것으로 사료되 어 적용하였으며, 유한요소실험은 응력에 대해 그 비례 로 결과가 나타남으로 비교분석을 위해 $250 \mathrm{~N}$ 으로 가하 였다.

임플란트 예후를 결정하는 중요한 요소는 임플란트와 치밀골이 만나는 경부 주위 치밀골의 흡수 여부이므로, 이 부위의 응력집중 정도가 임플란트의 예후를 보장하 기 위해 중요하다고 생각되어 참고점 중 1과 6점의 응력 을 평균하여 비교하였다.

임플란트의 길이에 따른 응력분포에서 길이가 짧을수 록 임플란트 주위골에서의 응력집중이 심하여, 임상에
서 임플란트를 식립할 때 잔존치조골이 허락하는 한 가 능한 긴 임플란트의 식립을 하여야 할 것으로 사료된다. 또한 지대치 응력분포에는 임플란트 길이가 크게 영향 을 미치지 않는 것으로 나타났다. 무치악 부위에는 임플 란트 길이가 짧을수록 응력집중이 증가되었는데 이는 하중에 따른 임플란트 $\mathrm{Y}$ 축 변위의 증가로 인한 것으로 사료된다.

임플란트의 위치가 응력분산에 미치는 영향에 있어 서, Cunha 등 ${ }^{21}$ 과 Verri 등 ${ }^{5}$ 은 임플란트가 지대치에 가 까이 갈수록 지대치에 가해지는 응력은 감소한다고 하 였는데, 이번 연구에서도 임플란트가 제1대구치 위치에 있을 때 지대치에 가해지는 응력이 많이 감소하였으나, 대신에 임플란트에 많은 응력이 집중하였다. 건전한 지 대치일 경우, 임플란트를 사용하지 않은 대조군 모델 $\mathrm{G}$ 의 지대치에 부하되는 응력 정도는 견딘다고 생각할 때, 제1대구치 부위에 임플란트를 식립하는 것은 지대치에 적은 하중이 분산되는 대신, 임플란트에는 심한 응력이 집중되고 후방 무치악 부위에도 응력이 많이 작용하므 로 부적절하다고 생각된다. 그러므로 임플란트의 식립 위치는 제 2 대구치 부위 혹은 그 후방이 더 적절하다고 사료된다. 이번 연구에서는 제 2 소구치 위치에 임플란트 식립을 고려하지 않았는데, 여러 문헌에서는 제2소구치 의 임플란트 식립이 지대치의 응력을 감소시키는 위치 상의 장점이 있다고 보고하고 있다. 그러나 이번 연구의 결과에 비추어보면, 무치악부에는 더욱 응력이 집중되 어 후방연장 국소의치의 단점을 해결하려는 목적으로 볼 때, 이것에 대한 분석은 의미가 없다고 보았다.

또한 수직 단일하중을 줌으로 의치의 휨이 발생하여 임플란트에 수직적인 하중으로 분산되지 않고 근심에서 원심으로 가해지는 양상을 나타내어 임플란트 원심부위 치조골에 응력이 집중되었다. 참고점 중 1 과 6 번을 비교 하면 모델 A에서는 원심인 6번에서 1번에 비해 약 10배 의 응력집중이 관찰되었으나, 모델 $\mathrm{B}, \mathrm{C}$ 에서는 각각 1.6 배와 1.2 배로 낮아지는 것으로 나타났다. 그러나, 모델 $\mathrm{D}, \mathrm{E}, \mathrm{F}$ 에서는 임플란트 경부 치조골에서 원심부 응력 이 근심보다 약간 높았으나 전체적으로 높은 응력집중 에 비하여 그 정도가 미미하였다. 따라서 무치악 원심부 에 임플란트를 식립할 경우에는, 원심으로 향하는 응력 을 예방하기 위한 방법을 고려하여야 할 것으로 사료된 다.

지대치에 미치는 응력은 대조군인 모델 $\mathrm{G}$ 에 비하여 모델 $\mathrm{D}, \mathrm{E}, \mathrm{F}$ 에서 매우 감소한 것을 볼 수 있었으나, 모 
델 $\mathrm{A}, \mathrm{B}, \mathrm{C}$ 에서는 약간 감소하였다. 그러므로 지대치가 건전하지 못하여 지대치를 보조하거나 대용으로 임플란 트가 사용될 경우에는 보다 지대치에 가깝게 식립하는 것이 좋을 것으로 사료된다. 반대로 후방 무치악부에서 는 모델 $\mathrm{A}, \mathrm{B}, \mathrm{C}$ 보다 모델 $\mathrm{D}, \mathrm{E}, \mathrm{F}$ 에서 증가된 응력집중 이 관찰되어, 무치악부 지지를 위해서는 무치악부 원심 에 임플란트를 식립하는 것이 유리하다는 것을 볼 수 있 었다.

이러한 응력분포를 고려할 때, 모델 $\mathrm{A}$ 의 경우는 현재 임상에서 성공적으로 사용이 보고되는 상황이어서 임플 란트에 가해지는 응력을 경부 치밀골이 견딜 수 있다고 가정할 수 있다. 이번 실험에서 모델 $\mathrm{A}$ 에 비하여 모델 B 에서 약 2.3 배 그리고 모델 C에서 약 3배의 응력집중에 골유착이 유지될 수 있는지에 대해서는 현 실험에서 적 절한 답을 내기는 어려울 것이다. 그러나, 모델 $\mathrm{D}$ 에 비 하여 모델 B에서 약 $53 \%$ 그리고 모델 C에서 약 $71 \%$ 의 응력집중이 나타나, 짧은 임플란트의 예후를 위한 관점 에서 원심 무치악부에 임플란트를 식립하는 것이 성공 할 가능성이 크다는 것을 알 수 있었으며, 제 2대구치 위 치보다 원심에 식립하면 더욱 유리할 것임을 예측할 수 있었다.

변위분석에 있어서, $\mathrm{X}$ 축에서 일어나는 변위는 수직 하중과 지대치 원심 레스트 지점에 의한 의치의 회전으 로 아주 작은 양만 일어났으나, 원심 레스트가 아닌 근 심 레스트를 사용할 경우에 변위가 더욱 감소할 것으로 예상된다. $\mathrm{Y}$ 축에서의 변위는 단일 수직하중에 따른 의 치의 휨과 하중의 힘에 따라서 비례적으로 일어나 응력 의 집중이 되는 곳에서 더 많은 변위가 일어났다.

이번 연구에서 지대치로 사용될 경우가 아닌, 후방연 장 국소의치 증례의 의치지지를 위해서 사용될 임플란 트의 식립은 가능한 무치악부의 원심에 심는 것이 유리 하고 또한 충분히 긴 임플란트를 사용하는 것이 좋을 것 으로 사료된다. 그러나 어떤 길이의 임플란트가 기능적 으로 견딜 수 있는지에 대해서는 더 많은 연구가 필요하 며, 보다 정확히 구강 내 환경을 재현할 수 있는 3 차원 모델에서 수직응력뿐만 아니라 다양한 방향의 응력을 재현하는 등의 지속적인 연구가 있어야 할 것으로 사료 된다.

\section{결론}

후방연장 국소의치에 의치지지를 위한 임플란트의 사
용시 수직 단일하중 하에서 응력분산에 미치는 영향에 대 한 2차원 유한요소분석에서 다음과 같은 결론을 얻었다.

1. 무치악 치조골의 응력 분산을 위한 관점에서, 임플 란트의 식립 위치는 무치악부 원심에 식립하는 것 이 유리하다.

2. 임플란트의 길이는 가능한 충분히 긴 것이 유리하 나, 어느 정도의 길이가 응력에 견딜 수 있는 지에 대해서는 더 많은 연구가 필요하다.

\section{Acknowledgements}

이 논문은 2012학년도 경북대학교 학술연구비에 의하 여 연구되었음.

\section{Orcid}

Jin-Hyun Cho http://orcid.org/0000-0002-2453-9372

Cheong-Hee Lee http://orcid.org/0000-0002-2005-0801

\section{References}

1. Kim SK, Yoo SY, Park IP, Lee JH. Implants in conjunction with removable partial denture. J Korean Dent Assoc 2011;49:77-84.

2. Kordatzis K, Wright PS, Meijer HJ. Posterior mandibular residual ridge resorption in patients with conventional dentures and implant overdentures. Int J Oral Maxillofac Implants 2003;18:447-52.

3. Giffin KM. Solving the distal extension removable partial denture base movement dilemma: a clinical report. J Prosthet Dent 1996;76:347-9.

4. Keltjens HM, Kayser AF, Hertel R, Battistuzzi PG. Distal extension removable partial dentures supported by implants and residual teeth: considerations and case reports. Int J Oral Maxillofac Implants 1993;8:208-13.

5. Verri FR, Pellizzer EP, Rocha EP, Pereira JA. Influence of length and diameter of implants associated with distal extension removable partial dentures. Implant Dent 2007;16:270-80.

6. Witter DJ, de Haan AF, Käyser AF, van Rossum GM. A 6-year follow-up study of oral function in shortened dental arches. Part I: Occlusal stability. J Oral Rehabil 1994;21:113-25. 
7. Jorge JH, Quishida CC, Vergani CE, Machado AL, Pavarina AC, Ciampaolo ET. Clinical evaluation of failures in removable partial dentures. J Oral Sci 2012;54:337-42.

8. Shahmiri R, Aarts JM, Bennani V, Das R, Swair MV. Strain distribution in a Kennedy class I implant assisted removable partial denture under various loading conditions. Int J Dent 2013;2013:351279.

9. Wills DJ, Manderson RD. Biomechanical aspects of the support of partial denture. J Dent 1977;5:310-8

10. Itoh H, Caputo AA, Wylie R, Berg T. Effects of periodontal support and fixed splinting on load transfer by removable partial dentures. J Prosthet Dent 1998;79:465-71.

11. Tebrock OC, Rohen RM, Fenster RK, Pelleu GB Jr. The effect of various clasping systems on the mobility of abutment teeth for distal-extension removable partial dentures. J Prosthet Dent 1979;41:5116.

12. Starr NL. The distal extension case: an alternative restorative design for implant prosthetics. Int J Periodontics Restorative Dent 2001;21:61-7.

13. Monteith BD. Management of loading forces on mandibular distal-extension prostheses. Part I: Evaluation of concepts for design. J Prosthet Dent 1984;52:673-81.

14. Shahmiri RA, Atieh MA. Mandibular Kennedy class I implant-tooth-borne removable partial denture: a systematic review. J Oral Rehabil 2010;37:225-34.

15. Mijiritsky E, Ormianer Z, Klinger A, Mardinger O. Use of dental implants to improve unfavorable removable partial denture design. Compend Contin Educ Dent 2005;26:744-746,748,750 passim.

16. Pellizzer EP, Verri FR, Falcon-Antenucci RM, Goiato MC, Gennari Filho H. Evaluation of differ- ent retention systems on a distal extension removable partial denture associated with an osseointegrated implant. J Craniofac Surg 2010;21:727-34.

17. Ohkubo C, Kobayashi M, Suzuki Y, Hosoi T. Effect of implant support on distal-extension removable partial dentures: in vivo assessment. Int J Oral Maxillofac Implants 2008;23:1095-101.

18. Bortolini S, Natali A, Franchi M, Coggiola A, Consolo U. Implant-retained removable partial dentures: an 8-year retrospective study. J Prosthodont 2011;20:168-72.

19. Grossmann Y, Nissan J, Levin L. Clinical effectiveness of implant-supported removable partial dentures: a review of the literature and retrospective case evaluation. J Oral Maxillofac Surg 2009;67: 1941-6.

20. Lee JH, Kim DG, Park CJ, Cho LR. A literature review on implant assisted removable partial denture. J Dent Rehabil Appl Sci 2012;28:179-90.

21. Cunha LD, Pellizzer EP, Verri FR, Pereira JA. Evaluation of the influence of location of osseointegrated implants associated with mandibular removable partial dentures. Implant Dent 2008;17:278-87.

22. Wheeler RC. Dental anatomy, physiology and occlusion. 5th ed. Philadelphia; WB Saundders Co.; 1974. p. 185-194\&216-28.

23. Pellecchia M, Pellecchia R, Emtiaz S. Distal extension mandibular removable partial denture connected to an anterior fixed implant-supported prosthesis: a clinical report. J Prosthet Dent 2000;83:60712.

24. Chronopoulos V, Sarafianou A, Kourtis S. The use of dental implants in combination with removable partial dentures: a case report. J Esthet Restor Dent 2008;20:355-64; discussion 365. 


\section{후방연장 가철성 국소의치에서 임플란트의 길이와 위치가 응력분산에 미치는 영향}

\section{김진희, 조진현, 이청희*}

경북대학교 치의학전문대학원 치과보철학교실

목적: 임플란트 위치와 길이가 하악 후방연장 가철성 국소의치(DERPD)와 연관된 임플란트의 응력 분포와 변위에 미 치는 영향을 알아보는 것이다.

연구 재료 및 방법: \#35, 36, 37이 소실된 시상절단면의 후방연장모형과 가철성 국소의치를 기본모형으로 사용했다. $\mathrm{NX} 9.0$ 으로 7개의 모델을 디자인했다. 모델 A, B, C에서 각각 $11,6,4 \mathrm{~mm}$ 길이의 임플란트가 \#37 인공치 하방에 위치 되었다. 모델 D, E, F에서 각각 11, 6, $4 \mathrm{~mm}$ 의 임플란트가 \#36 인공치 하방에 위치되었다. 모델 G는 임플란트가 없었 다. 수직하중 $(250 \mathrm{~N})$ 을 \#36의 중심와에 가했고, 유한요소 분석프로그램을 이용해 von Mises stress와 변위를 관찰했다. 결과: \#37에 위치한 임플란트는 \#36에 위치한 것과 비교시 주변골에 더 낮은 응력집중도를, \#36에 위치한 임플란트 는 \#37에 위치한 것보다 더 적은 변위를 보였다.

결론: 임플란트 지지형 가철성 국소의치에서 후방부에 위치한 임플란트는 전방부에서보다 더 이점을 가지며, 길이가 더 긴 임플란트의 사용은 응력분산을 위해서 중요하다.

(구강회복응용과학지 2015;31 (3): 186-94)

주요어: 임플란트 지지형 가철성 국소의치; 후방연장 가철성 국소의치; 임플란트 길이; 응력 분산 